
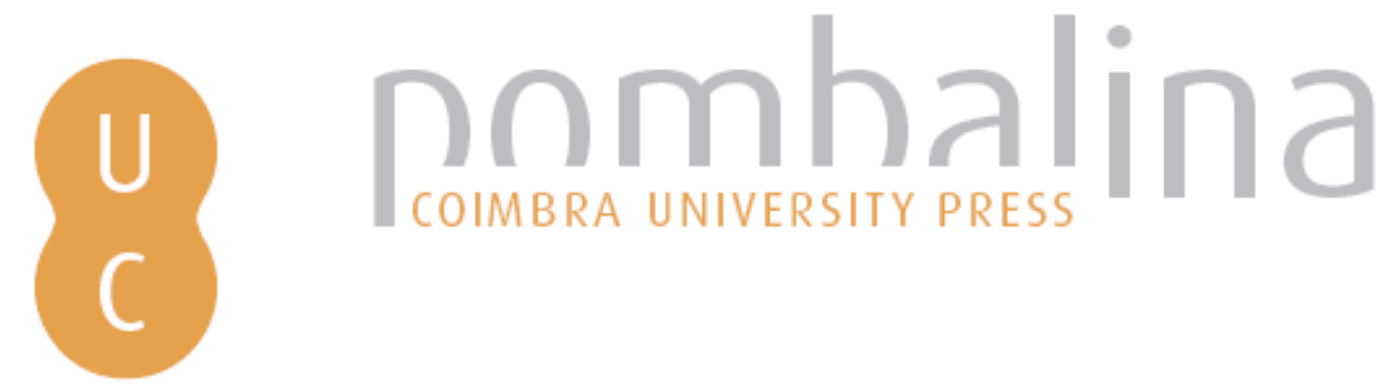

\title{
Os privilégios das bibliotecas nas leis de direito de autor nos países da União Europeia: análise comparativa
}

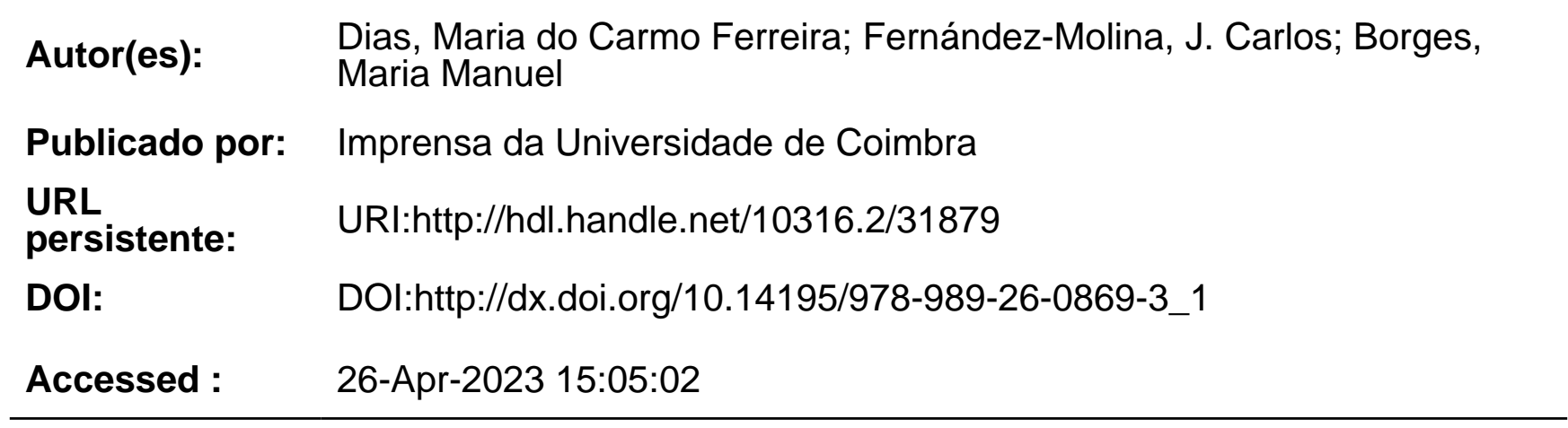

A navegação consulta e descarregamento dos títulos inseridos nas Bibliotecas Digitais UC Digitalis, UC Pombalina e UC Impactum, pressupõem a aceitação plena e sem reservas dos Termos e Condições de Uso destas Bibliotecas Digitais, disponíveis em https://digitalis.uc.pt/pt-pt/termos.

Conforme exposto nos referidos Termos e Condições de Uso, o descarregamento de títulos de acesso restrito requer uma licença válida de autorização devendo o utilizador aceder ao(s) documento(s) a partir de um endereço de IP da instituição detentora da supramencionada licença.

Ao utilizador é apenas permitido o descarregamento para uso pessoal, pelo que o emprego do(s) título(s) descarregado(s) para outro fim, designadamente comercial, carece de autorização do respetivo autor ou editor da obra.

Na medida em que todas as obras da UC Digitalis se encontram protegidas pelo Código do Direito de Autor e Direitos Conexos e demais legislação aplicável, toda a cópia, parcial ou total, deste documento, nos casos em que é legalmente admitida, deverá conter ou fazer-se acompanhar por este aviso.

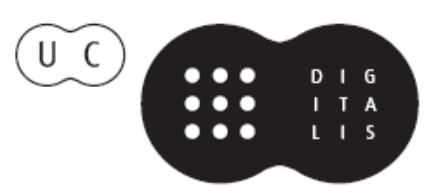


Maria Manuel Borges

Elias Sanz Casado

Coordenação

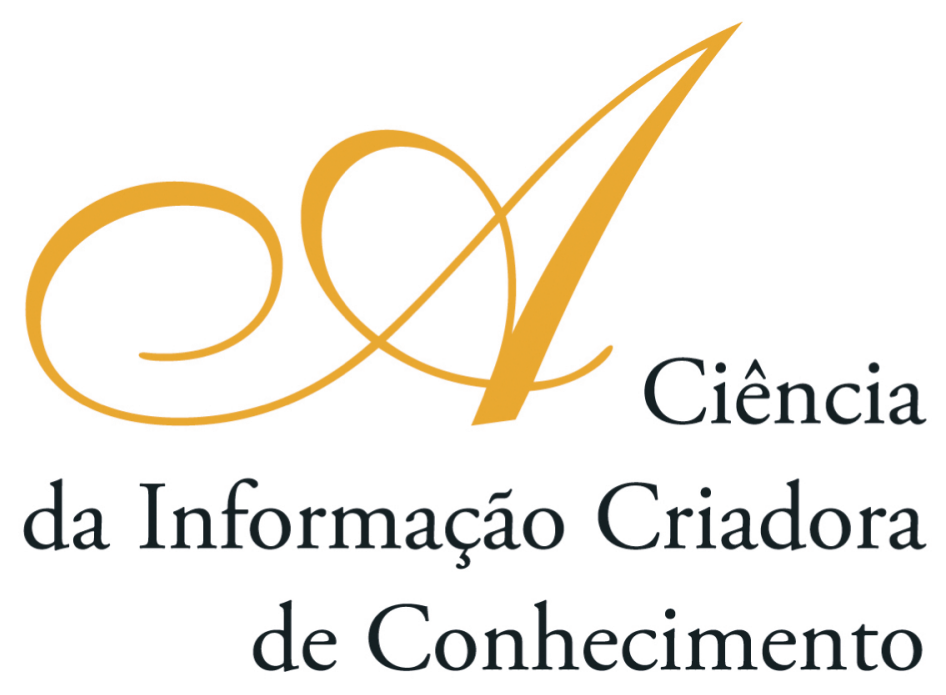

Vol. I I

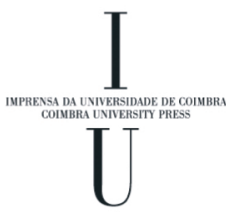

- COImbra 2009 


\title{
Os privilégios das Bibliotecas nas Leis de Direito de Autor nos Países da União Europeia: Análise comparativa
}

Maria do Carmo Ferreira Dias

Universidade de Coimbra (Portugal)

J. Carlos Fernández-Molina

Universidad de Granada (Espanha)

Maria Manuel Borges

Universidade de Coimbra (Portugal)

\section{Resumo}

O desenvolvimento da sociedade de informação e das novas tecnologias digitais introduziram alterações significativas no âmbito do Direito de Autor, principalmente, na criação e difusão das obras intelectuais e no papel desempenhado pelas Bibliotecas na disponibilizaçáo dessas obras para o público. Estas modificações introduziram algumas alterações às disposiçóes legislativas sobre o Direito de Autor, quer a nível internacional, comunitário ou nacional. Destacaremos as limitaçóes e excepçóes ao Direito de Autor, que se encontram presentes nas legislaçôes e que beneficiam as Bibliotecas, nos quinze Estados membros mais antigos da União Europeia.

\begin{abstract}
The development of the information society and of the new digital technologies has introduced significant alterations within the framework of the copyrights, mainly, in the creation and diffusion of the intellectual properties and within the role played by Libraries in regards to the availability of those works to the public. These changes have brought some modifications to the provisions laid down by law concerning the Copyrights, be it at international, national or community level. We will point out the limitations and exceptions of the Copyrights, which can be found under laws and that, are an advantage to Libraries, in the fifteen older Member States of the European Union
\end{abstract}

\section{Introdução}

O Direito de Autor consiste num Direito que remonta até à Antiguidade Clássica, mas que continua presente e actual nos nossos dias. As características da sociedade de informação, o desenvolvimento das novas tecnologias de informação e de comunicação originaram alteraçôes profundas na esfera dos Direitos de Autor. A sua abordagem situa-se num contexto diferente e a sua importância continua a ser reconhecida a nível internacional e como tal, procurou-se legislar sobre a matéria, numa tentativa de harmonizaçáo e de adaptaçáo deste ramo do direito às novas condiçóes do mundo 
actual. Nesta linha, é aprovada a Convenção de Berna, que instituiu as traves mestras do direito de autor e que serviu de base para as posteriores legislaçóes neste domínio. Ainda no âmbito internacional, convém destacar a acção e a importância da Organização Mundial da Propriedade Intelectual (OMPI) e dos Tratados celebrados no âmbito desta organização, bem como o Acordo TRIPS, acordo esse celebrado entre a OMPI e a Organização Mundial do Comércio. A nível comunitário, as disposiçóes da Directiva sobre o Direito de Autor na Sociedade de Informação conduziram a reformas e à harmonização das legislaçôes dos Estados membros.

As leis sobre o Direito de Autor integram dois aspectos essenciais: por um lado o incremento da criação e difusão das obras, fruto da acção criadora do Homem e, por outro, a facilitação do acesso às obras, por parte dos utilizadores. Entre estes dois elementos deve existir um certo equilíbrio, que é concretizado através das disposiçóes patentes, nas leis sobre Direito de Autor e que dizem respeito às excepçóes e limitaçóes a esses direitos.

Nas várias legislaçóes, quer internacionais, quer comunitárias, quer, ainda, nos vários países, as normas sobre o direito de autor, apresentam algumas disposiçôes de excepção, nomeadamente para as Bibliotecas, que dispóem o legado colectivo da memória cultural e científica, promovendo a leitura e fomentando a cultura. Estas excepçóes constituíam autênticos privilégios para as Bibliotecas, procurando estabelecer um equilíbrio de interesses dos criadores e detentores dos Direitos de Autor e o público em geral, sempre com o intuito de facilitar o acesso e a livre circulação da informaçáo.

As excepçóes ou privilégios em favor das Bibliotecas foram proliferando com o carácter cada vez mais internacional do Direito de Autor, com as novas legislaçóes internacionais sobre a matéria e com o incremento do papel desempenhado pelas Bibliotecas na sociedade de informação. Estas excepções ou privilégios incidem sobre as questóes relacionadas com a reproduçáo de obras protegidas pelos Direitos de Autor, para determinados objectivos, como a investigação e estudo, preservação e substituição de materiais, para acesso aos documentos e para o empréstimo interbibliotecas.

A nossa reflexão incidirá sobre a aplicação das disposições comunitárias, neste domínio, nomeadamente a aplicação da Directiva Comunitária 2001/29/CE, nos Países mais antigos da União Europeia: Alemanha, Áustria, Bélgica, Dinamarca, Espanha, Finlândia, França, Grécia, Holanda, Irlanda, Itália, Luxemburgo, Portugal, Reino Unido e Suécia. A fonte de informação utilizada para a recolha das Leis consistiu na Base de Dados CLEA (Collection of Laws for Electronic Access), mantida e actualizada pela Organização Mundial da Propriedade Intelectual (OMPI).

\section{Os Limites do Direito de Autor}

O Direito de Autor constitui um direito que vai buscar as suas origens à civilização da Antiguidade Clássica e que se desenvolveu com a invenção da imprensa e com a revolução industrial. Desde cedo se procurou legislar sobre um domínio tão importante e especial como refere Garrett (1849), citado por Pereira (2001, p.113): «a mais indefesa, porém, a mais nobre e a mais inquestionável de todas as propriedades, a que se cria pela inteligência e pelo espírito do Homem». A sua evolução «reflecte o desenvolvimento da tecnologia», como escreve Stewart (1989), citado por Pereira (2001, p.113). 
O Direito de Autor incide sobre as criaçōes originais do espírito do Homem. É considerado um direito comum; um direito civil; um direito natural; um direito fundamental do Homem, consagrado na Declaração Universal dos Direitos do Homem e na Carta dos Direitos Fundamentais da União Europeia e um direito constitucional, na medida em que se encontra patente nas constituiçôes dos vários países. Estamos perante um direito de cultura, em virtude de incidir sobre as obras literárias, artísticas e científicas, que constituem o património da Humanidade.

A nível internacional, procurou-se legislar sobre tão importante domínio e, principalmente, procurou-se harmonizar este direito, esbatendo as diferenças existentes nos diversos Países. Assim, foi aprovada a Convenção de Berna, que lançou as bases do Direito de Autor e que serviu de ponto de partida para as posteriores legislaçôes neste domínio. Esta Convenção menciona algumas disposiçóes relativas às excepçóes ou limitaçôes, deixando a sua regulação ao critério dos diversos países. Apenas estipula uma, a que consta do art. $10^{\circ}$ do texto da Convenção. Este artigo refere que «são lícitas as citaçôes tiradas de uma obra já licitamente tornada acessível ao público, na condição de serem conformes aos bons costumes e na medida justificada para o fim a atingir...» (OMPI, 1979).

Ainda no âmbito internacional, convém destacar a acção e a importância da Organização Mundial da Propriedade Intelectual (OMPI), nomeadamente, com os diversos Tratados celebrados no âmbito desta organização, como o Tratado da OMPI de 1996, bem como o Acordo TRIPS, acordo esse celebrado entre a OMPI e a Organização Mundial do Comércio.

O Tratado da OMPI de 1996 marcou o ponto de viragem das reformas das diversas leis nacionais de Direito de Autor, para as adaptar ao mundo digital e náo olvidou as limitaçôes ao Direito de Autor, sempre de acordo com a defesa dos direitos fundamentais e do interesse público. Apresenta aspectos fundamentais para o nosso estudo, nomeadamente o art. $10^{\circ}$, que concede a possibilidade de os Países intervenientes poderem "prever, nas suas legislaçóes nacionais, limitações ou excepçóes aos direitos concedidos aos autores se obras literárias e artísticas», salvaguardando a «exploração normal da obra» e algum "prejuízo injustificado aos interesses legítimos do autor»(OMPI, 1996). Estabelece que os privilégios concedidos às Bibliotecas possam ser aplicados e ampliados no universo do digital e, ainda, a possibilidade de ser criados novos privilégios, para uma correcta adaptação às novas realidades tecnológicas (Fernández-Molina et al., 2008).

A nível comunitário, várias Directivas foram aprovadas sobre o Direito de Autor, sendo a mais importante a Directiva 2001/29/CE, que incide sobre a harmonização de certos aspectos do Direito de Autor e dos direitos conexos na sociedade de informação.

Estabelece algumas disposições obrigatórias para os Estados membros e outra de carácter facultativo, em que se inclui a excepçáo em favor das Bibliotecas. Permite, ainda, que os Estados membros ampliem essas excepçôes ou limitaçôes, abrangendo, também, o direito de distribuição (Crews, 2008).

A legislação sobre o Direito de Autor procurou alicerçar as bases de um direito tão importante, uma tentativa de harmonizar as várias legislaçôes dos diversos países e, ainda, pressupóe fomentar do acto de criação intelectual das obras e a sua difusão, conferindo uma panóplia de direitos e faculdades aos titulares dos Direitos de Autor, 
nomeadamente aos autores, editores ou produtores. Promove, também, o acesso fácil e rápido às obras intelectuais por parte dos utilizadores, beneficiando a sociedade com o acesso à informação e ao conhecimento. Entre estes dois aspectos essenciais devem coexistir um equilíbrio, que é conferido por determinadas disposiçóes patentes na legislação, que constituem excepçóes e limitaçóes aos direitos consagrados nas leis (Fernández-Molina, 2003).

As excepçóes e as limitações são várias e dependem de determinados aspectos, nomeadamente a defesa dos direitos fundamentais, as competências, o interesse público e as imperfeiçóes do mercado (Guibault, 2002). O interesse público encontra-se na base dos privilégios atribuídos às Bibliotecas e instituiçôes similares, tais como os Museus, os Arquivos, as Hemerotecas, etc., destacando as funçóes destas instituiçóes, como por exemplo: a colecção, a preservação e a difusão da informação. Estas funçóes originam cópias, distribuição e comunicaçáo pública das obras, objecto do direito de autor.

Estas limitaçóes revestem-se de grande importância e encontram-se patentes nas legislações de vários países, apesar de algumas diferenças existentes. Estas diferenças aludem ao tipo de actos que são ou não permitidos, às renumeraçóes exigidas e ao tipo de instituições que beneficiam destes privilégios. São permitidas na medida em que as instituiçóes que as praticam desenvolvem funçóes de preservação e de difusão da informação, concedendo benefícios para a sociedade e promovem o bem comum.

\section{Os Privilégios das Bibliotecas}

Os privilégios conferidos às Bibliotecas são considerados factores muito importantes para a acção das Bibliotecas na nossa sociedade de informação e, principalmente, na difusão rápida da informação. Constituem determinados benefícios e vantagens atribuídos às Bibliotecas, que prestam um serviço público, ou a determinadas instituiçôes de carácter cultural ou científico, sem fins comerciais. Os privilégios são determinadas prerrogativas que as Bibliotecas estão autorizadas a praticar, sempre tendo em consideração as suas finalidades de conservação, de preservação e de divulgação da informação. Estes privilégios, concedidos pela legislação às Bibliotecas, são considerados como limitações e excepçóes ao direito de autor, que se caracteriza por não ser um direito absoluto.

Estas excepçóes ao Direito de Autor apresentam uma aplicação restringida, em relação ao conjunto de direitos atribuídos aos titulares de direito de autor. Permitem, por exemplo, cópias de algumas obras, mas de acordo com determinados objectivos, sendo os mais comuns a investigação e a preservação.

Consistem essencialmente, na possibilidade de reprodução de obras protegidas pelo direito de Autor, de comunicação pública, de distribuição e de colocação à disposição dos utilizadores, por parte de Bibliotecas ou outras instituiçóes similares. Estas instituiçôes caracterizam-se por serem instituiçóes públicas, sem fins lucrativos e por prestarem serviços à comunidade. Guardam, tornam acessível e preservam o património documental (Dreier, 2001).

Estes privilégios abarcam, também, o universo do digital e não devem prejudicar a normal exploração da obra, nem táo pouco, colidir com os interesses dos direitos de autor. 
As disposições legais relativamente às excepções são uma realidade em quase todos os Países. Contudo, algumas legislações nacionais são omissas quanto a este ponto. Dos Países membros da Organização Mundial da Propriedade Intelectual, só uma pequena minoria não contém legislação sobre o Direito de Autor. Mas, o facto de algumas legislaçôes nacionais não apresentarem referências quanto às excepçôes auferidas às Bibliotecas, não significa que estas instituiçóes não possam proceder, por meios considerados lícitos a cópias e outras práticas de obras protegidas pelo Direito de Autor.

As Bibliotecas que reúnem as condições necessárias para a concessão dos ditos privilégios, devem ser de natureza pública, sem fins lucrativos, deter uma missão na sociedade e oferecer um serviço público à comunidade. Algumas legislaçóes referem, também, os Arquivos. O reconhecimento por parte dos legisladores, revela o papel importantíssimo para a sociedade que as Bibliotecas e as outras instituiçóes desenvolvem na sociedade. Não podemos esquecer que as Bibliotecas, através da possibilidade das cópias para preservação, por exemplo, estão a garantir o legado cultural e patrimonial da Humanidade. Tal como refere Crews (2008, p.36): «las bibliotecas tienen evidentemente un papel principal en el contexto de la legislación sobre derecho de autor».

As cópias permitidas dependem do tipo de material, que é lícito copiar. Algumas legislaçóes podem permitir copiar todo o tipo de obras, mau grado, outros imponham certas restriçôes no tipo de obras. Estas limitaçôes são reveladoras da utilização de certos tipos de obras pelas Bibliotecas e podem transmitir a própria influência das Bibliotecas e dos titulares do Direito de Autor. Importa referir, ainda, que as Bibliotecas dispóem, cada vez mais, nos seus fundos de obras em suporte digital e que, tal como as obras em suporte de papel podem ser efémeras, torna-se urgente proceder a cópias para preservação documental futura. Deste modo, as legislaçóes abordam esta questão, mas por vezes de maneira mais ou menos directa.

As Bibliotecas, de acordo com as normas estabelecidas, podem utilizar as obras protegidas pelo Direito de Autor, sem proceder a compensaçóes aos autores ou aos titulares. Esta possibilidade depende do tipo de excepçôes conferidas pela legislação em causa e do tipo de licenças existentes. Podem, também, conter disposiçóes relativas ao pagamento dos serviços bibliotecários, bem como, algumas outras condiçóes como a indicação para incluir o nome do autor ou a fonte, na cópia efectuada.

Das excepçóes mais importantes, cumpre destacar as excepçóes gerais que permitem às Bibliotecas efectuar a reprodução de obras protegidas pelos Direitos de Autor, sem nenhum objectivo específico e com alguma flexibilidade. Mas a par das excepçóes gerais, podemos considerar outros tipos, como:

\section{- As excepçóes para fins de investigação e estudo}

As disposiçôes legais neste domínio encontram-se patentes em quase todas as legislações. As excepçóes para fins de investigação ou para fins de estudo podem ser caracterizadas por serem excepçóes gerais ou excepçóes mais específicas. As mais gerais permitem a cópia sem restriçóes e as mais específicas podem permitir cópias para todo o tipo de obras ou apenas para algumas obras específicas (as pertencentes às colecçóes das próprias Bibliotecas ou obras publicadas). As obras náo publicadas são objecto de uma atenção particular, em virtude dos problemas que originam. Por vezes, nalgumas situaçóes exige-se prova da finalidade da cópia. 
Mas estas excepçôes para fins de investigação ou de estudo, não se restringem somente à possibilidade de se efectuarem cópias. Referem-se, também, à colocação à disposição dos utilizadores.

- As excepções para fins de preservação e substituição

A preservação e a conservação dos fundos documentais das Bibliotecas representam aspectos muito relevantes e para cumprir estes fins, torna-se necessário efectuar, por meios considerados lícitos, cópias das obras, protegidas pelos Direitos de Autor. Existem certas restriçóes, nas quais podemos nomear: o número de cópias autorizado, cópias das obras existentes nas colecçóes das Bibliotecas, o facto de a cópia passar ou não a fazer parte do espólio da Biblioteca e a existência de alguma situaçáo de lucro. Estas excepções estão associadas ao facto de a obra estar ou não disponível no mercado e de ser ou não uma obra original. A questão da preservação é bastante importante, na medida em que, com a proliferação das obras em formato digital, outros problemas surgem, como por exemplo, o desconhecimento da duração dos novos suportes. Torna-se urgente tomar medidas para preservar a informação. A Comissão da União Europeia, numa iniciativa denominada Biblioteca Digital Europeia, estabeleceu algumas recomendaçóes, nas quais se destaca a permissão para as bibliotecas puderam efectuar as cópias, consideradas necessárias, para garantir um elevado grau de preservação da documentação, independentemente do seu suporte.

- As excepçóes para fornecimento de documentos ou para empréstimos interbibliotecas

Esta excepção é de grande relevância, em virtude de, permitir o acesso aos fundos documentais de outras Bibliotecas.

\section{A Directiva Comunitária de 2001/29/CE}

Os objectivos da União Europeia prendem-se com a promoção do progresso económico e social equilibrado e sustentável, com a criação de um espaço interno sem fronteiras, o reforço da coesão económica e social e o estabelecimento da união económica e monetária. As políticas comuns são reforçadas, bem como a defesa dos direitos e dos interesses dos nacionais dos Estados membros, com o estabelecimento da cidadania da união, de acordo com o princípio da subsidiariedade. A harmonização das políticas e das legislaçóes contribuirá para a prossecução do mercado interno e para as liberdades fundamentais. Nesta linha, desenvolveram-se directivas comunitárias para colmatar as diferenças existentes. A nível do âmbito do Direito de Autor, algumas directivas estabeleceram regras, de acordo com os tratados internacionais, para regular a matéria. Como já referimos, a Directiva 2001/29/CE detém um papel considerável na tentativa de harmonizar o Direito de Autor na sociedade de informação.

Dois artigos do texto da Directiva revelam grande importância para o nosso estudo. Consistem nos art. $5^{\circ}$, n. 2, alínea c) e $5^{\circ}$, n. 3, alínea n). O artigo $5^{\circ}$, n.2, alínea c) confere a possibilidade de se prever excepçôes ou limitaçóes ao direito de reprodução, mais concretamente, para «actos específicos de reproduçáo praticados por bibliotecas (...), que não tenham por objectivo a obtenção de uma vantagem económica ou 
comercial, directa ou indirecta» (Uniāo Europeia, 2001). O art. 5º, n. 3, alínea n) alarga o âmbito das limitaçôes ou excepções, incidindo, também, sobre a «utilização por comunicação ou colocação à disposição, para efeitos de investigação ou estudos privados, a membros individuais do público por terminais destinados para o efeito nas instalaçôes referidos na alínea c) do no 2, de obras e outros materiais (...)» (União Europeia, 2001).

O texto da Directiva permite, por um lado, que sejam praticados actos de reprodução, efectuados pelas Bibliotecas acessíveis ao público e sem o objectivo de obter alguma vantagem económica. O que realça nesta disposição consiste no tipo de Bibliotecas, que podem ser públicas ou privadas, mas, apenas, devem ser acessíveis ao público, náo se exigindo qualquer renumeração para os titulares dos Direitos de Autor. Por outra banda, reconhece o direito de comunicaçáo pública e o direito de colocação à disposição, com a finalidade de investigação e de estudo. Recai sobre as obras da colecção, não englobando as obras fruto de empréstimo interbibliotecas e estipula que o acesso seja processado em terminais nas instalaçóes das próprias Bibliotecas e sempre que essas obras, não estejam disponíveis no mercado.

Esta disposição da Directiva limita a importância desta excepção. E, podemos referir, que é omissa quanto à circulação de obras na Internet (Garrote, 2001). Mas mau grado, estes entraves, podemos referir e destacar a importância da preservação de obras de difícil acesso ou em mau estado de conservação.

No que concerne à regulação da protecção tecnológica, as medidas caracterizam-se por serem muito restritivas, náo permitindo o acto de contornamento das medidas tecnológicas, bem como de certas actividades que facilitem essa acção. Estas medidas podem comprometer as limitaçóes e as excepçôes aos Direitos de Autor. Procurou-se colmatar esta situação com um possível estabelecimento de um equilíbrio de interesses entre os titulares dos Direitos de Autor e os utilizadores. Mas este equilíbrio é bastante ténue e continua a não incidir sobre as obras em linha. Este facto origina que as limitaçóes ou excepçóes aos Direitos de Autor sejam comprometidas, principalmente a nível do ambiente digital.

\section{Análise comparativa da aplicação da Directiva 2001/29/CE nos 15 Estados Membros mais antigos da União Europeia}

Os Estados membros da União Europeia transpuseram para as suas ordens jurídicas internas as disposiçóes da Directiva 2001/29/CE. Alguns Estados membros limitaramse a transcrever o texto da Directiva, mas outros adaptaram algumas disposiçóes às suas realidades jurídicas, sociais e culturais.

As excepções são permitidas nestes países em determinadas situaçôes. E no seio delas podemos identificar a preocupação pela investigação, pelo estudo, pela preservação, pela divulgação, pela substituição, com o objectivo de perpetuar a memória da Humanidade.

Assim, podemos destacar as várias excepções nos quinze Estados membros, mais antigos da União Europeia:

- Alemanha: as excepçóes destinam-se à investigação e ao estudo, nas Bibliotecas, Museus e Arquivos, que sejam acessíveis ao público e que não tenham fins lucrativos. As 
cópias que se podem efectuar incidem sobre artigos ou partes de obras, por solicitação dos utilizadores, independentemente do objectivo em causa.

- Austria: são praticadas nos estabelecimentos acessíveis ao público, sem existir, propriamente uma finalidade concreta e sem fins comerciais, permitindo a cópia das obras e, em certas circunstâncias, a cópia digital.

- Bélgica: as excepçôes dizem respeito à preservação do património cultural e científico, sem qualquer finalidade económica, à substituição e às tecnologias obsoletas, à investigação e, finalmente ao estudo, por parte das Bibliotecas, Museus e Arquivos, que se encontram acessíveis ao público.

- Dinamarca: excepçóes para preservação e para substituição, nas Bibliotecas e nos Arquivos públicos, sem fins comerciais, com o recurso a cópias digitais de obras e de artigos, mas de acordo com uma licença colectiva ampliada e com uma renumeraçáo requerida pelo titular.

- Espanha: os Museus, as Fonotecas, as Filmotecas, as Hemerotecas e os Arquivos podem utilizar as excepçôes com a finalidade da investigação e da preservação, não possuindo qualquer tipo de lucro e devem ser instituiçôes públicas ou formar parte de instituições de carácter cultural e científico. As obras que podem ser copiadas e comunicadas são as obras da colecção. Abrangem o empréstimo e as cópias para uso pessoal.

- Finlândia: as excepçôes destinam-se à preservação, à substituição, à administração de Bibliotecas, à investigação e ao estudo, em instituiçôes públicas, tais como as Bibliotecas, Arquivos e Museus, sem fins lucrativos. Asseguram a possibilidade de as Bibliotecas puderem efectuar cópias de artigos, que foram publicados e cópias de outras obras e, ainda, cópias de obras cujos materiais são susceptíveis de se deteriorarem. Estas cópias passíveis de serem concretizadas destinam-se para uso privado dos utilizadores das Bibliotecas.

- França, as excepçóes têm por objectivo a preservação e a conservação, nas Bibliotecas, Museus e Arquivos acessíveis ao público, sem qualquer vantagem económica ou comercial. As cópias a efectuar são das obras da Biblioteca.

- Grécia: as excepções visam a utilização para utilização bibliotecária, de modo a preservar o fundo documental, nas Bibliotecas e nos Arquivos, sem fins lucrativos.

- Holanda: as excepçôes possíveis são as cópias para preservação, substituição e tecnologias obsoletas, para a investigação, nas Bibliotecas, Museus e Arquivos acessíveis ao público, sem fins económicos ou comerciais. As cópias que podem realizar-se são as das obras literárias, artísticas e científicas que constituem os fundos das referidas instituições.

- Irlanda: as disposiçóes existentes referem a investigação, o estudo, as cópias de obras de outras Bibliotecas, a preservação e a substituição e para a própria administração das Bibliotecas, realizáveis por profissionais das Bibliotecas e dos Arquivos autorizados. As cópias podem ser dos artigos ou do índice das publicações periódicas, das obras colocadas à disposição, das obras da colecção, de publicaçóes periódicas ou artigos de outras Bibliotecas.

- Itália: as excepções incidem sobre a investigação e o estudo, a utilização para uso bibliotecário, para pedidos pessoais dos utilizadores, por Bibliotecas, estabelecimentos docentes, Museus e Arquivos acessíveis ao público. As obras que podem ser copiadas são as obras da colecção da instituição ou obras de outras instituiçôes. 
- Luxemburgo: as cópias podem ser realizadas para efeitos de preservação, por parte das Bibliotecas, instituiçóes educativas, Museus e Arquivos, sem vantagens comerciais, quer directas, quer indirectas. A finalidade da cópia reside na preservação e salvaguarda do património. As cópias possíveis são as cópias acessíveis e à disposição do público. Contudo, os actos de reprodução não devem comprometer a norma exploração da obra, nem prejudicar os interesses dos autores.

- Portugal: as excepçóes dizem respeito às cópias das obras, por motivos de substituição, não se especificando uma finalidade concreta. As instituiçóes que podem efectuar as cópias são as Bibliotecas acessíveis ao público, as instituiçóes educativas, os Museus e os Arquivos.

- Reino Unido: as disposiçóes sobre esta matéria caracterizam-se por desceram muito ao pormenor. As excepções abarcam a preservação, a substituição, as cópias de artigos ou de obras pedidas a outras Bibliotecas, a investigação e o estudo. A legislação permite conhecer o objectivo das cópias pedidas pelos utilizadores e constatar que as Bibliotecas ou os Arquivos autorizados prestam um serviço de cópias de documentos, de acordo com a lei em vigor. As cópias lícitas consistem na cópia das obras, nos pedidos de cópias a outras Bibliotecas, nas cópias de artigos de Publicaçóes periódicas, nas cópias de excertos de obras e de obras não publicadas.

- Suécia: as excepçôes têm por objectivo a preservação, a investigação e, ainda, para completar obras incompletas, por parte das Bibliotecas públicas e científicas e dos Arquivos. Permite a cópia de artigos e certas partes das obras e a cópia das obras, por motivos de segurança ou de preservação. As excepçóes dizem respeito a obras de suporte em papel. As cópias das obras em formato digital só são possíveis, mediante, a existência de uma licença colectiva.

Como se constata, as várias legislaçóes destes quinze Estados membros mais antigos da Uniâo Europeia, abordam a questão dos denominados privilégios ou excepçóes que usufruem as Bibliotecas. As normas em vigor resultam do esforço de harmonizaçáo da legislação, levada a cabo pelas instituiçóes comunitárias. Deste modo, os vários Estados transpuseram para as ordens jurídicas internas as disposiçóes vigentes nas directivas, mais concretamente as patentes na Directiva 2001/29/CE. Mau grado o grau de harmonização, denota-se que, apesar de existem disposiçôes que são comuns a todos os Estados, constatam-se certas divergências entre os vários países aqui consignados, o que pode provocar alguns problemas nesta matéria.

Todos os quinze Estados, aqui analisados sob o ponto de vista do Direito de Autor, apresentam semelhanças na legislação, como por exemplo, o facto de todos considerarem as Bibliotecas e algumas instituiçôes similares como beneficiárias dos privilégios dos Direitos de Autor. Importa, pois, ressalvar que estas instituiçóes caracterizam por serem públicas e sem fins lucrativos. Este facto realça o papel que as Bibliotecas desempenham na nossa sociedade, como detentoras da memória cultural e científica da Humanidade. As Bibliotecas desempenham um papel fundamental na preservação do património cultural do Homem. "Typical functions of any library are the collection, preservation, archiving, and dissemination of information" (Guibault, 2003, p.12). As Bibliotecas são uma «força viva para a educação, cultura e informação..." (UNESCO, 1994).

Verifica-se, também, que a maior parte das excepçóes ou limitaçóes ao Direito de Autor dizem respeito à preservação, à substituição, a situaçóes para contemplar as obras 
e à conservação dos fundos documentais. Aludem, ainda, à investigação e ao estudo. Estas excepções destacam a acção que as Bibliotecas desenvolvem na comunidade, fornecendo as condiçôes necessárias para o processo de aprendizagem do Homem e contribuindo para o desenvolvimento cultural. Outras diferenças consistem no tipo de obras que podem ser objecto de cópia. Nalguns Estados, as disposiçôes divergem quanto ao tipo de obras. Alguns Países consideram todo o tipo de obras, enquanto noutros as limitaçôes existentes estão bem presentes. Nem todos os Estados permitem as cópias digitais. Quase todos permitem a cópia privada, para uso dos utilizadores da Biblioteca. Todos os Estados propóem medidas de protecção contra o contornamento das medidas tecnológicas.

Convém referir que todos os actos de reprodução permitidos não devem comprometer a norma exploração da obra, nem prejudicar os interesses legítimos dos autores.

Tabela comparativa que indica as finalidades e as excepçóes permitidas, no âmbito das limitaçóes do Direito de Autor, nos quinzes Países mais antigos da União

\section{Europeia}

\begin{tabular}{|c|c|c|}
\hline Países & Finalidade & Excepçóes \\
\hline Alemanha & $\begin{array}{l}\text { Investigação } \\
\text { Estudo privado } \\
\text { Para utilizaçáo privada }\end{array}$ & $\begin{array}{l}\text { Cópias das obras da colecção } \\
\text { Cópias de artigos publicados para os utilizadores } \\
\text { Medidas contra a "elusión» das medidas } \\
\text { tecnológicas }\end{array}$ \\
\hline Áustria & Utilização pela Biblioteca & $\begin{array}{l}\text { Cópias das obras publicadas } \\
\text { Cópia digital } \\
\text { Medidas contra a «elusión» das medidas } \\
\text { tecnológicas }\end{array}$ \\
\hline Bélgica & $\begin{array}{l}\text { Preservação } \\
\text { Substituição e restauração do } \\
\text { exemplar } \\
\text { Tecnologias obsoletas } \\
\text { Investigação e Estudo }\end{array}$ & $\begin{array}{l}\text { Cópias das obras literárias, científicas e artísticas } \\
\text { dos fundos da instituiçáo } \\
\text { Empréstimo público } \\
\text { Medidas contra a "elusión» das medidas } \\
\text { tecnológicas }\end{array}$ \\
\hline Dinamarca & $\begin{array}{l}\text { Preservação, } \\
\text { Garantir a sua durabilidade } \\
\text { Substituiçáo } \\
\text { Exigência de uma Licença } \\
\text { colectiva ampliada e de uma } \\
\text { remuneração }\end{array}$ & $\begin{array}{l}\text { Cópias das faltas na colecção, obras não } \\
\text { disponíveis, obras publicadas, partes de obras } \\
\text { em formato digital } \\
\text { Disposiçáo, cópia de obras depositadas } \\
\text { Medidas contra a «elusión» das medidas } \\
\text { tecnológicas }\end{array}$ \\
\hline Espanha & $\begin{array}{l}\text { Investigação } \\
\text { Preservação }\end{array}$ & $\begin{array}{l}\text { Cópias das obras } \\
\text { Empréstimo público } \\
\text { Medidas contra a «elusión» das medidas } \\
\text { tecnológicas }\end{array}$ \\
\hline Finlândia & $\begin{array}{l}\text { Preservação, garantia da } \\
\text { durabilidade, reconstrução } \\
\text { técnica e restauraçáo do material } \\
\text { Administração e organização } \\
\text { das colecçóes das Bibliotecas, } \\
\text { Substituição e finalização de uma } \\
\text { obra incompleta } \\
\text { Investigação e Estudo }\end{array}$ & $\begin{array}{l}\text { Obras das colecçōes da instituição e obras } \\
\text { consideradas vulneráveis, } \\
\text { Cópias para protecção dos direitos de autor } \\
\text { Medidas contra a "elusión» das medidas } \\
\text { tecnológicas }\end{array}$ \\
\hline
\end{tabular}




\begin{tabular}{|c|c|c|}
\hline França & $\begin{array}{l}\text { Preservaçáo } \\
\text { Cópias para os utilizadores }\end{array}$ & $\begin{array}{l}\text { Cópias das obras } \\
\text { Medidas contra a «elusión» das medidas } \\
\text { tecnológicas }\end{array}$ \\
\hline Grécia & $\begin{array}{l}\text { Cópias para uso bibliotecário } \\
\text { Conservação }\end{array}$ & $\begin{array}{l}\text { Cópias das obras da colecçáo } \\
\text { Cópias para outras Bibliotecas } \\
\text { Medidas contra a «elusión» das medidas } \\
\text { tecnológica }\end{array}$ \\
\hline Holanda & $\begin{array}{l}\text { Preservaçáo } \\
\text { Substituiçắo } \\
\text { Tecnologias obsoletas } \\
\text { Investigação e Estudo }\end{array}$ & $\begin{array}{l}\text { Cópias das obras da colecçáo } \\
\text { Empréstimo público } \\
\text { Medidas contra a "elusión» das medidas } \\
\text { tecnológicas }\end{array}$ \\
\hline Irlanda & $\begin{array}{l}\text { Investigação e Estudo } \\
\text { Preservação } \\
\text { Substituiçãa } \\
\text { Administração de Bibliotecas }\end{array}$ & $\begin{array}{l}\text { Cópias dos artigos ou do índice das publicaçóes } \\
\text { periódicas, das obras colocadas à disposiçăo, das } \\
\text { obras da colecção, de publicaçōes periódicas ou } \\
\text { artigos de outras Bibliotecas } \\
\text { Exportação de obras de importância cultural e } \\
\text { empréstimo público } \\
\text { Medidas contra a "elusión» das medidas } \\
\text { tecnológicas }\end{array}$ \\
\hline Itália & $\begin{array}{l}\text { Investigaçáo e Estudo } \\
\text { Cópias para uso bibliotecário } \\
\text { Cópias para utilizadores }\end{array}$ & $\begin{array}{l}\text { Cópias das obras e dos materiais da colecção } \\
\text { Cópias de obras de outras Bibliotecas } \\
\text { Cópias para preservaçấo de emissôes e } \\
\text { fonogramas } \\
\text { Medidas contra a «elusión» das medidas } \\
\text { tecnológicas }\end{array}$ \\
\hline Luxemburgo & $\begin{array}{l}\text { Preservação } \\
\text { Salvaguarda do património }\end{array}$ & $\begin{array}{l}\text { Cópias acessíveis } \\
\text { Cópias à disposição do público } \\
\text { Medidas contra aelusión» das medidas } \\
\text { tecnológicas }\end{array}$ \\
\hline Portugal & Substituição & $\begin{array}{l}\text { Cópias das obras } \\
\text { Medidas contra a "elusión» das medidas } \\
\text { tecnológicas }\end{array}$ \\
\hline $\begin{array}{l}\text { Reino } \\
\text { Unido }\end{array}$ & $\begin{array}{l}\text { Preservaçáo } \\
\text { Substituiçãao } \\
\text { Investigaçáo e Estudo }\end{array}$ & $\begin{array}{l}\text { Cópias das obras, cópias pedidas a outras } \\
\text { Bibliotecas, cópias de artigos de publicaçóes } \\
\text { periódicas, cópias de fragmentos de obras, } \\
\text { cópias de obras não publicadas } \\
\text { Declaraçóes confirmadas, empréstimo, etc. } \\
\text { Medidas contra a "elusión» das medidas } \\
\text { tecnológicas }\end{array}$ \\
\hline Suécia & $\begin{array}{l}\text { Preservação } \\
\text { Completar obras incompletas } \\
\text { Investigaçáo } \\
\text { Exigência de uma licença } \\
\text { colectiva para cópias digitais }\end{array}$ & $\begin{array}{l}\text { Cópias das obras } \\
\text { Cópias de artigos ou partes de obras por razóes } \\
\text { de segurança e de preservaçáo } \\
\text { Medidas contra a «elusión» das medidas } \\
\text { tecnológicas }\end{array}$ \\
\hline
\end{tabular}

\section{Consideraçóes Finais}

Este trabalho apresenta as características essenciais das legislaçôes sobre Direito de Autor dos quinze Estados membros mais antigos da União Europeia, de acordo com as linhas gerais das Directiva 2001/29/CE. Constatamos que em determinadas situaçóes são permitidas excepçóes ou limitaçóes ao Direito de Autor, que constituem privilégios 
para as Bibliotecas, instituiçôes de carácter público e sem fins lucrativos. As excepçóes centram-se, fundamentalmente, na preservação, na conservação, na substituição, em completar as obras incompletas do fundo das Bibliotecas, na própria administração das Bibliotecas, na investigação e no estudo. A regulação das medidas tecnológicas está presente em todas as disposiçôes legislativas, dos países que considerámos.

Nos países como a Bélgica, a Dinamarca, a Espanha, a Finlândia, a França, a Holanda, a Irlanda, o Luxemburgo, Reino Unido e a Suécia, a primazia das excepçôes recai sobre a preservação e a substituição. Em Portugal, apenas incide sobre a substituição. $\mathrm{Na}$ Grécia, o destaque reside na conservação e no Luxemburgo na salvaguarda do património. A Holanda não esquece os casos em que as tecnologias se encontram obsoletas. Na Alemanha, na Bélgica, na Espanha, na Holanda, na Irlanda, na Itália, no Reino Unido e na Suécia, podemos referir as excepçôes para a investigação e para o estudo. Na Áustria, na Finlândia, na Grécia, na Irlanda e na Itália, as excepçōes visam a própria administração das Bibliotecas. A Dinamarca e a Suécia têm a particularidade da exigência de uma licença colectiva.

Os Estados membros considerados apresentam algumas diferenças quanto aos tipos de obras que são considerados, mas só alguns é que permitem a cópia digital.

Estas excepçóes destacam o papel importante que as Bibliotecas desenvolvem na sociedade, mais concretamente, no fomento da cultura, do ensino, da investigação e do estudo e na preservação dos fundos documentais, que constituem o património da Humanidade. Importa salientar que estes privilégios não devem prejudicar a normal exploração da obra, nem os interesses dos titulares dos Direitos de Autor.

\section{Reconhecimentos}

Este trabalho tem o apoio do Ministerio de Ciencia e Innovación de España, Proyecto CSO-2008-03817/SOCI.

\section{Referências Bibliográficas}

Crews, K. (2008). Estudio sobre las limitaciones y excepciones al derecho de autor en beneficio de bibliotecas y archivos (Comité Permanente de Derecho de Autor y Derechos Conexos, OMPI). [Em linha]. [Consulta em 16 de Julho de 2009]. Disponível em:

http://www.wipo.int/edocs/mdocs/copyright/es/sccr_17/sccr_17_2.pdf

Dreier, T. (2001). Towards consensus on the electronic use of publications in libraries. Göttingen: SUB.

Fernández-Molina, J. C. (2003). Protección tecnológica y contractual de las obras con derecho de autor: ¿Hacia una privatización de la información? Ciência da Informação, 32(2), 54-63.

Fernández-Molina, J.C., Dias, M.C. \& Borges, M.M. (2008). Bibliotecas y derechos de autor: análisis comparativo de la nueva legislación de España y Portugal. In: Frías, J.A. y Travieso, C., eds. Información, investigación y mercado laboral en información y documentación en España y Portugal. Salamanca: Universidad de Salamanca, 801-811. 
Garrote, I. (2001). El derecho de autor en Internet. La directiva sobre derechos de autor y derechos afines en la sociedad de la información. Granada: Comares.

Guibault, L. (2002). Copyright limitations and contracts: an analysis of the contractual overridability of limitations on copyright. The Hague: Kluwer Law International.

Guibault, L. (2003). The nature and scope of limitations and exceptions to copyright and neighbouring rights with regard to general interest missions for the transmission of knowledge: prospects for their adaptation to the digital environment. e-Copyright Bulletin. [Em linha]. [Consulta em 16 de Julho de 2009]. Disponível em:

http://unesdoc.unesco.org/images/0013/001396/139671e.pdf

OMPI (1979). Convenção de Berna: relativa à protecção das obras literárias e artísticas. [Em linha]. [Consulta em 16 de Julho de 2009]. Disponível em:

http://www.wipo.int/treaties/fr/ip/berne/trtdocs_wo001.html

OMPI (1996). Tratado de la OMPI sobre Derecho de Autor. [Em linha]. [Consulta em 16 de Julho de 2009]. Disponível em:

http://www.wipo.int/treaties/es/ip/wct/trtdocs_wo033.html

Pereira, Alexandre Dias (2001). Informática, direito de autor e propriedade tecnodigital. Coimbra: Coimbra Editora.

Portugal (2004). Lei no 50/2004 de 24 de Agosto, transposição para a ordem jurídica nacional da Directiva 2001/29/CE, do Parlamento Europeu e do Conselho, de 22 de Maio de 2001, relativa à harmonizaçáo de certos aspectos do direito de autor e dos direitos conexos na sociedade da informação. Diário da República, I-A Série 199 (24.08.2004), p.5658-5665.

UNESCO (1994). Manifesto da UNESCO sobre Bibliotecas Publicas. [Em linha]. [Consulta em 16 de Julho de 2007]. Disponível em: http://www.ifla.org/VII/s8/unesco/port.htm

União Europeia (2001). Directiva 2001/29/CE, do Parlamento Europeu e do Conselho, de 22 de Maio de 2001, relativa à harmonizaçáo de certos aspectos do direito de autor e dos direitos conexos na sociedade da informação. Jornal Oficial das Comunidades Europeias. Série L, no 167 (2001), p.10-19. [Em linha]. [Consulta em 11 de Dezembro de 2008]. Disponível em:

http://eur-lex.europa.eu/LexUriServ/LexUriServ.do?uri=OJ:L:2001:167:0010:0019:PT:PDF 